\title{
EM BUSCA DE SI, DO MUNDO E DA POESIA: A OBRA MODERNA DE BLAISE CENDRARS
}

\section{ARAUJO, Natalia Aparecida Bisio de ${ }^{1}$}

RESUMO: Blaise Cendrars foi um dos homens mais cosmopolitas de seu tempo, pois viajou pelo mundo desde a infância e possuiu uma identidade nacional fragmentada. Em sua vida itinerante, o escritor presenciou fatos que transformaram o início do século $\mathrm{XX}$, como as revoluções tecnológicas, que ofereceram à sociedade variadas máquinas que facilitariam a vida da população. Nesse contexto, a poesia de Cendrars constituiu-se tanto por uma busca do autor por si mesmo, por seu ser permeado pela pluralidade cultural de sua formação, quanto pela predileção da modernidade vivida pelo seu tempo. A figura de Blaise Cendrars, sua poesia moderna e a representação do espírito vanguardista se misturam com os relatos do escritor de suas experiências pelo mundo. Por meio de um embasamento teórico a partir de teorias e críticas da poesia em geral, assim como estudos sobre a poesia de vanguarda no início do século XX, este trabalho apresentará como a obra do escritor almeja a expressão do mundo moderno, das novas concepções poéticas e das suas próprias experiências.

PALAVRAS-CHAVE: Blaise Cendrars, Modernidade Poética, Vanguardas Europeias, Poética de si.

\section{À LA RECHERCHE DE SOI, DU MONDE ET DE LA POÉSIE: L'EUUVRE MODERNE DE BLAISE CENDRARS}

\footnotetext{
${ }^{1}$ Mestre em Estudos Literários pela Universidade Estadual Paulista - UNESP - Araraquara-SP. Doutoranda em Estudos Literários pela mesma instituição, com financiamento pela CAPES. Atua no ensino de literatura e de língua francesa. Contato: natalia-bisio@hotmail.com.
} 
RÉSUMÉ : Blaise Cendrars a été l'un des hommes les plus cosmopolites de son époque car il a voyagé par le monde depuis son enfance et il a possédé une identité nationale fragmentée. Dans sa vie itinérante, l'auteur a été témoin des événements qui ont révolutionné le début du XXe siècle, comme les révolutions technologiques, qui ont offert à la société plusieurs machines qui ont facilité la vie de la population. Dans ce contexte, la poésie de Cendrars s'est constitué autant par une recherche de l'auteur par soi-même, par son être pénétrée par la diversité culturelle de sa formation, comme par la prédilection de la modernité vécu dans son temps. La figure de Blaise Cendrars, sa poésie moderne et la représentation de l'esprit d'avantgarde se mélangent avec les récits de l'auteur de leurs expériences par le monde. À partir des théories et des critiques de la poésie en général, ainsi que des études sur la poésie d'avantgarde au début du XXe siècle, , ce travail présentera présentera comment l'œuvre de l'auteur cherche l'expression du monde moderne, des nouvelles conceptions poétiques et de ses propres expériences.

MOTS-CLÉS : Blaise Cendrars, Modernité poétique, Avant-gardes Européenne, Poétique du soi.

\section{INTRODUÇÃO}

Blaise Cendrars nasceu em Chaux-de-Fonds na Suíça, em 1887, e foi registrado com o nome de Frédéric-Louis Sauser. O poeta está situado entre os artistas da modernidade mais cosmopolitas de seu tempo. Com uma família itinerante, Cendrars foi afastado de sua terra natal desde o berço e conheceu diversos cantos do planeta. Viajou e possuiu estadias em várias cidades do mundo, como Paris, São Paulo, Buenos Aires, Cannes, Hoollywood, Nova Yorque, São Petersburgo, Alexandria, Nápoles, Brindisi e Neuchâtel. O poeta sempre falou da fragmentação da sua identidade nacional, composta por suas várias experiências pelo mundo desde a infância. Viveu sempre em busca de aventuras, lugares novos e outras culturas, as quais estudava com afinco. Os 70 anos de vida do escritor foram marcados tanto pela agitação de sua obra moderna quanto por suas viagens pelo mundo.

Além disso, é preciso dizer que, de Frédéric-Louis Sauser ao pseudônimo Blaise Cendrars, o próprio poeta também se fez a grande personagem de sua obra, de modo que o seu "eu" e a constante busca de si foram também a base de seus versos. No ensaio “Cendrars: fantasia e realidade”, publicado no Diário Crítico (1960), Sergio Milliet discute que "sem dúvida, a julgar pelos pormenores espantosos das viagens de 
Blaise Cendrars, [...] a obra do poeta lhe reflete a vida com uma fidelidade absoluta" (MILLIET, 2001, p. 445). O poeta acreditava que o retorno constante em si mesmo traria sempre o novo, a inspiração para sua obra moderna: “[o] escritor que faz muitos retornos em si mesmo, como eu, nunca sobe pela mesma escada, nunca desce no mesmo porão, nunca está no topo da mesma torre, ele descobre constantemente o novo $[\ldots]^{2 »}\left(\right.$ CENDRARS, 2006a $\mathrm{a}^{\mathrm{a}}$, p. 76).

Para o poeta, vida e arte são inseparáveis, de modo que a poesia é um instrumento para sua própria vivência e experiência no mundo. Em um artigo para a revista Der Sturm, em 1913, Cendrars explica como o ato de escrever é tido como aperfeiçoamento e extensão de sua vida:

Eu não sou poeta. Eu sou libertino. Não tenho nenhum método de trabalho. Eu tenho um sexo. Eu sou excessivamente sensível. Eu não sei falar objetivamente sobre mim mesmo. Todo ser vivo é uma fisiologia. E se eu escrevo, talvez seja por necessidade, por higiene, como se come, como se respira, como se canta. Talvez seja por instinto: talvez por espiritualidade. [...] Também pode ser para treinar, para existir - para existir na vida, mais e mais! A literatura faz parte da vida. Não é algo 'à parte'. Eu não escrevo por profissão. Viver não é uma profissão. Portanto, não há artistas. Os organismos vivos não trabalham. [...] Toda vida é só um poema, um movimento. Eu sou apenas uma palavra, um verbo, uma profundidade, no sentido mais selvagem, mais místico, mais vivo ${ }^{3}$. (CENDRARS, 1987, p. 99)

\footnotetext{
${ }^{2}$ Tradução nossa. "L'écrivain qui fait de nombreux retours sur lui-même, comme moi, ne monte jamais par le même escalier, ne descend jamais dans la même cave, n'est jamais au sommet de la même tour, il découvre sans cesse et toujours du nouveau [...]".

${ }^{3}$ Tradução nossa. "Je ne suis pas poète. Je suis libertin. Je n'ai aucune méthode de travail. J'ai un sexe. Je suis par trop sensible. Je ne sais pas parler objectivement de moi-même. Tout être vivant est une physiologie. Et si j'écris, c'est peut-être par besoin, par hygiène, comme on mange, comme on respire, comme on chante. C'est peut-être par instinct: peut-être par spiritualité. [...] C'est peut-être aussi pour m'entraîner, pour m'exister - pour m'exister à vivre, mieux, tant et plus! La littérature fait partie de la vie. Ce n'est pas quelque chose "à part". Je n'écris pas par métier. Vivre n'est pas un métier. Il n'y a donc pas d'artistes. Les organismes vivants ne travaillent pas. [...] Toute vie n'est qu'un poème, un mouvement. Je ne suis qu'un mot, un verbe, une profondeur, dans le sens le plus sauvage, le plus mystique, le plus vivant".
} 
Por ser "excessivamente sensível" e não conseguir organizar sua vida de modo objetivo, escrever é para Cendrars atividade vital, indispensável, como o comer ou o respirar. A atividade artística, longe de ser encarada como um trabalho, torna-se inseparável do poeta, a ponto de sua essência não mais se desprender da obra, o produto final de seu viver. Assim, com uma identidade nacional fragmentada, somada à predileção por viagens, o próprio poeta torna-se o protagonista de seus versos, afirmando buscar na poesia uma maneira de encontrar a si mesmo e de conjugar seu ser permeado pela pluralidade cultural de sua formação.

Instaura-se, consequentemente, um impasse na poesia do escritor: a realidade e o biografismo, pela relação inegável entre vida e obra, contrastada com o ficcional. Ao mesmo tempo em que Cendrars toma como referência vários episódios de sua vida como matéria-prima para seus versos, também faz o contrário: muitos dados que giram em torno da biografia do poeta não encontram arquivos severos na realidade factual. Como um verdadeiro artista, que chegou a elaborar um pseudônimo para assinar suas obras, Cendrars também cria alguns dados biográficos que estão envolvidos na atmosfera ficcional e artística de sua figura como poeta. Sergio Milliet comenta a imaginação poderosa do poeta ao misturar dados ficcionais aos biográficos:

\footnotetext{
Assim era Cendrars, o mais admirável dos mentirosos, o mais divertido dos companheiros, pois tudo vira, tudo sabia, tudo vivera sem sair de Paris... No entanto, nunca Cendrars ficou em Paris, pois a vida efetiva que levava não era aquela dos cafés e dos ateliês mas a outra, a do mundo de sua imaginação, do mundo imenso, milionário, de aventuras mirabolantes, que existia para ele e por ele, no qual ele era herói n ${ }^{\circ}$ 1. (MILLIET, 2001, p. 446)
}

Vale lembrar que toda essa forma de envolver arte e vida provinha do discurso vanguardista, com o qual Cendrars muito se identificou. A Vanguarda possuía um desejo de romper com as técnicas estéticas do passado - como força antagonista frente à tradição - e de construir uma arte revolucionária, militante de novos rumos do objeto artístico e que, ao mesmo tempo, fosse a expressão de sua contemporaneidade repleta 
de inovações. Nesse sentido, conforme afirma Peter Bürger (1993, p. 90,91), junto de toda a retórica destrutiva vanguardista, havia o objetivo de se restaurar os laços entre arte e vida, de modo que os movimentos surgiram como reação ao esteticismo da arte burguesa, que em seu autotelismo, desligou-se da "práxis vital". Assim como os poetas de vanguarda, Cendrars também acreditava que a poesia deveria ser a expressão de seu tempo, pois a vida moderna havia criado naturalmente uma série de elementos completamente novos.

E tal como fez Cendrars, os vanguardistas expressaram a sua contemporaneidade por meio de suas próprias experiências. Como a figura dos poetas estava ligada a uma imensa rede de vivências e de variados espaços, possibilitados tanto pelas novas formas de circulação e de informações, quanto pelos avanços tecnológicos que encurtaram as distâncias do mundo, o entusiasmo com essas novas possibilidades tornou-se evidente nos assuntos poéticos. Como instrumento da experiência, a poesia de vanguarda foi muitas vezes o louvor à modernidade pelo escritor que, como homem moderno, vivenciou o novo. É nesse sentido que a obra de Blaise Cendrars muito se aproximou dos ideais da Vanguarda. Assim, o escritor passou a vida inteira buscando na própria modernidade de seu tempo a matéria de sua poesia.

Para revelar o mundo moderno, os vanguardistas precisavam de novas formas nas artes. De acordo com Weisgerber (1986), para expressar o "novo" vivido pelo mundo, os escritores renovariam não somente aspectos estruturais da poesia - como os princípios formais do verso, da estrofe, da imagem, dentre outros - mas atingiriam também a essência da lírica: buscava-se a purificação do gênero ou sua redução ao essencial. A procura pelo novo, somada à autonomia que os autores tinham para criar, fez com que cada poema se tornasse uma experiência única e inovadora. Foi assim que a vanguarda ficou conhecida como o grande "laboratório de experiência das artes", onde se trabalhava em busca de novos modos de expressão. Também nesse aspecto, a obra de Cendrars aproximou-se do ideal vanguardista, já que o poeta efetuou muitas experimentações, como a mistura do poético com outros gêneros artísticos - pintura, fotografia, cinema, música e propaganda -, a expressividade da tipografia e do espaço da página, a colagem e as imagens arquitetadas em diversos planos de visão fragmentados, superpostos e simultâneos. 
Cendrars aproxima-se das vanguardas, porém, não como militante dos movimentos, mas por participar de forma indireta desse pensamento de ruptura e de revolução, do libertário e do moderno que constituiu o pensamento vanguardista. Portanto, Cendrars não é estritamente futurista, cubista, ou expressionista, mas sim um artista das novas experimentações artísticas.

A obra do escritor acaba por evidenciar, assim, a figura do poeta em busca de sua identidade, do mundo moderno, e de sua poesia; um "eu" que afirma encontrar dentro de si mesmo a modernidade.

\section{Do mundo inteiro ao coração do mundo}

O título das poesias completas de Blaise Cendrars, reunidas com o título Du monde entier au cœur $d u$ monde $e^{4}$, revelam muito bem a trajetória da obra do escritor: um movimento que parte "do mundo inteiro", captando toda a sua modernidade, e atinge “o coração do mundo", a interioridade desse homem tão cosmopolita.

Conforme dito anteriormente, toda a obra poética do autor exalta as inovações vivenciadas pela sociedade do início do século $\mathrm{XX}$, por meio de suas viagens pelo mundo. Em Les Pâques à New York, a primeira obra poética, o escritor relata sua estadia em Nova Iorque, metrópole americana moderna, transpondo para o texto os barulhos estridentes dos trens, dos metropolitanos, das sirenes e dos meios de transporte. Os Dix-neuf poèmes élastiques aclama a Torre Eiffel, símbolo da modernidade e da era da máquina. La Prose du Transsibérien e Le Panama ou les aventures de mes sept oncles evidenciam a predileção pelos trens e sua rapidez. Em Documentaires, o poeta aponta com entusiasmo a modernidade e o progresso vividos pela América do Norte. Nas Feuilles de Route, livro sobre as viagens de Cendrars pelo Brasil, o escritor aclama o cosmopolitismo e a modernidade vivida por São Paulo.

Além de louvar as inovações do século XX, a obra de Cendrars também foi muito representativa do espírito das vanguardas, como já citado. Le Panama ou les

\footnotetext{
${ }^{4}$ A antologia teve uma primeira edição em 1947, com o título Poésies Complètes. É na segunda edição, em 1957, que surge o título Du monde entier au coeur du monde, que melhor representou o percurso da obra poética de Cendrars.
} 
aventures de mes sept oncles, de 1918, por exemplo, inova como os versos livres e brancos, a colagem, as palavras em liberdade e o prosaísmo. Porém, toda a modernidade vivida pelo mundo e até mesmo as características das vanguardas combinam-se com uma necessidade do poeta em expor a si mesmo a fim de encontrar as origens de sua identidade cultural fragmentada. O que mais marca Le Panama, por exemplo, é a figura do autor em uma constante busca de si. Na obra, o próprio escritor multiplicase na figura de seus sete tios a fim de encontrar-se como poeta e como homem moderno. Segundo Claude Leroy, “[...] os sete irmãos da mãe se apresentam como espelhos para um jovem poeta que busca ganhar a vida" 5 (LEROY, 2006 apud CENDRARS, 2006b, p. 362).

No poema, esses sete parentes são grandes cosmopolitas, homens que tiveram uma vida totalmente fora do comum e que viveram em exílio. Um deles morou no Alasca, outro, em Papeete. O quinto tio citado foi chefe gastronômico em várias cidades, como Chicago, "Nice Londres Buda-Pest Bermudes Saint-Pétersbourg Tokio Memphis" (CENDRARS, 2006b, p. 78). Já o sexto tio, partiu com astrônomos para estudar o céu na costa ocidental da Patagônia; enquanto o sétimo foi considerado o “dernier français au Panama [...] " (CENDRARS, 2006b, p. 84). Um deles morreu com um tiro de carabina na cabeça e outro, no ciclone de 1895, na Bélgica. O terceiro desapareceu durante doze anos e deixou a família sem nenhuma notícia dele, enquanto que o quarto enlouqueceu e morreu em um hospício. Apesar de não ser possível comprovar a veracidade das biografias descritas pelo poema, é relevante a construção da imagem da família de Cendrars, que tinha o gene do cosmopolitismo.

O que era comum aos tios, Cendrars expressa no refrão: "Et il y avait quelque chose/ La tristesse/ Et le mal du pays"7 (CENDRARS, 2006b, p. 72). É nesse ponto que encontramos a semelhança do poeta com os irmãos de sua mãe: “J'ai le mal du pays"8 (CENDRARS, 2006b, p. 85). Cendrars sente nostalgia, uma profunda melancolia causada por seu afastamento da terra natal, pois toda sua vida foi de viagens, com

\footnotetext{
5 Tradução nossa. "[...] les sept frères de la mère se présentent comme autant de miroirs pour un jeune poète cherchant à se faire une vie"

6 "o último francês no Panama [...]" (tradução nossa).

7 "E havia ainda alguma coisa/ A tristeza/ E a nostalgia" (tradução nossa).

8 “Terra Terra Água Oceanos Céus/ Eu tenho nostalgia” (tradução nossa).
} 
os recursos do mundo moderno, como os trens, tão apreciados pelo autor em toda a sua poesia. Para o escritor, segundo a obra, é essa situação de viajante, de modernidade e de cosmopolitismo que o tornou um poeta. Nesse ponto, atingimos a uma parte do título da obra: Le Panama. Nos seguintes versos, Cendrars afirma que "[...] le crach du Panama est d'une importance plus universelle/ Car il a bouleversé mon enfance"" (CENDRARS, 2006b, p. 68). Segundo o poema, essa grande transformação foi o fato de a família de Cendrars ter fugido da terra natal, porque o pai tinha se envolvido no escândalo da construção do canal do Panamá em 188910: "Mon père perdit les trois quarts de sa fortune/Comme nombre d'honnêtes gens qui perdirent leur argent dans le crach,/Mon père/ Moins bete/ Perdait celui des autres/ Coup de revolver,/ Ma mère pleurait [...] Nous avons dû déménager"11 (CENDRARS, 2006b, p. 68, 69).

Com as emoções de sua família errante, o poeta declara: "c'est le crach du Panama qui fit de moi un poète!"12 (CENDRARS, 2006b, p. 69), pois foi esse suposto acontecimento da infância de Cendrars que o fez, ainda criança, afastar-se de sua terra natal. Enfim, em seu mise-en-scène, Cendrars afirma que suas experiências pelo mundo, o espírito da modernidade, juntamente com o gene familiar itinerante - representado pela figura dos sete tios -, fizeram dele um poeta.

Além de Le Panama, outra obra marcante na carreira do escritor foi La Prose du Transsibérien et de la Petite Jehanne de France (1913), texto verbo-visual, produzido por Cendrars e pela pintora Sonia Delaunay-Terk. A obra era feita de uma única folha de papel, que se desdobrava como um acordeão em vinte e dois painéis, com a extensão de mais de dois metros. Ao lado esquerdo, a publicação possuía um longo painel de cores primárias brilhantes e de formas visuais abstratas, decompostas em vários planos geométricos e ângulos retos, que se sucedem e se interceptam. À direita,

\footnotetext{
9 “[...] o fracasso do [canal do] Panamá é de uma importância mais universal/ Pois ele transformou minha infância” (tradução nossa).

${ }^{10} \mathrm{O}$ Escândalo ligado à construção do Canal do Panamá foi considerado o maior caso de corrupção do século XIX, envolvendo altas personalidades, funcionários do governo e membros da imprensa francesa. A Companhia Universal do Canal Interoceânico do Panamá, fundada em 1879 pelo engenheiro francês Ferdinand de Lesseps, faliu e arruinou a numerosos acionistas. A companhia aliou-se ao governo e ambos adotaram um esquema de corrupção para manter silêncio sobre os problemas financeiros da empresa (LEROY, 2006 apud CENDRARS, 2006b, p. 362-363).

11 "Meu pai perdeu três quartos de sua fortuna/ Como muita gente honesta que perdeu seu dinheiro no fracasso [do canal],/ Meu pai/ Menos idiota/ Perdia o dinheiro dos outros,/ Tiros de revolver,/ Minha mãe chorava/ [...] Nós precisamos nos mudar" (tradução nossa).

12 "Foi o fracasso [do canal] do Panamá que fez de mim um poeta" (tradução nossa).
} 
o texto era precedido por um mapa da linha Transiberiana, com o trecho de Moscou ao mar do Japão. Abaixo desta figura, o poema segue composto de vários blocos tipográficos, grafados de diferentes cores, com o fundo da página também colorido, acompanhando os tons da pintura de Sônia Delaunay-Terk.

A obra causou grande impacto no meio literário mundial da época. Foi um sucesso, um grande acontecimento e ganhou espaço em exposições de Paris, Berlim, Londres, Moscou e São Petersburgo. Sua repercussão associou-se diretamente aos movimentos de vanguarda europeus, principalmente ao Cubismo e ao Futurismo, sobretudo por promover uma nova experimentação estética na literatura, como a mistura entre as artes plástica e poética ou a quebra de fronteiras entre os gêneros literários; além do culto à máquina e à velocidade, do emprego dos versos livres, das palavras em liberdade, da colagem, da expressividade da tipografia e da disposição dos versos pela página.

Além das marcantes características de vanguarda, outro traço marcante de $L a$ Prose é novamente a relação que mantém com os dados biográficos do poeta. No poema, Cendrars relata a longa viagem pelas linhas transiberianas, em 1904, realizada pelo jovem Sauser, antes de se tornar o escritor Cendrars. Naquela época, o poeta morava na Rússia, onde trabalhava para um comerciante dos mais variados tipos de bugigangas. Com esse sujeito, durante três anos, Cendrars vai atravessar pela primeira vez o mundo, percorrendo praticamente o trecho completo da linha transiberiana. A viagem de La Prose assemelha-se à experiência vivida pelo escritor. Na vida real e no

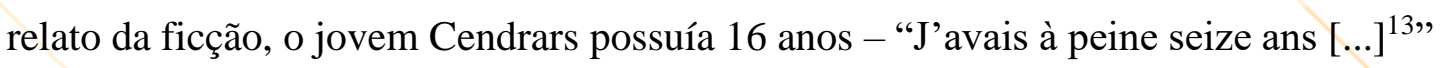
(CENDRARS, 2006b, p. 45) - e viajava com um comerciante rumo a Harbin- "Et je partis moi aussi pour accompagner le voyageur en bijouterie qui se rendait à

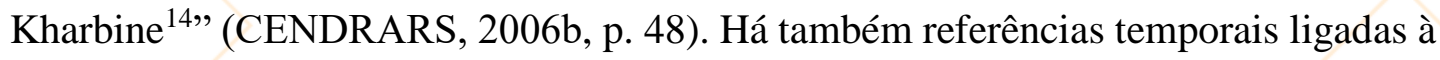
realidade, como o começo da guerra Russo-Japonesa - "En Sibérie tonnait le canon c'était la guerre ${ }^{15 "}$ (CENDRARS, 2006b, p. 47) - em 1904, data em que o jovem poeta estava na presença do vendedor. A viagem no Transiberiano é recriada artisticamente,

\footnotetext{
13 "Tinha apenas dezesseis anos [...]” (tradução de Sérgio Wax. CENDRARS, 1995, p. 23).

14 "E eu também parti para acompanhar o viajante de bijuterias que ia a Harbin" (tradução de Sérgio Wax. CENDRARS, 1995, p. 27).

15 "Na Sibéria troava o canhão, era a guerra" (tradução de Sérgio Wax. CENDRARS, 1995, p. 27).
} 
rompendo as fronteiras entre o mundo e o texto, ou seja, entre a realidade exterior e a elaboração artística que o representa.

Depois da Prose du Transsibérien, o poeta publica Dix-neuf poèmes élastiques em 1918. Assim como em toda a obra, é possível encontrar nos poemas inúmeras características ligadas aos movimentos de vanguarda, como as palavras em liberdade; versos livres e brancos; a predileção pelo mundo moderno e o culto à máquina e à velocidade; linguagem fragmentada, sobretudo pelas rupturas sintáticas; exemplos de colagem, como o caso do poema "Dernière heure", em que um artigo do jornal ParisMidi está transposto em versos. Porém, percebe-se, nessa obra, uma maior inclinação estética para algumas das vanguardas, como por exemplo, o Cubismo e do Expressionismo, quando se é exposta uma realidade desintegrada pela subjetividade do poeta. Em “Atelier” é possível notar as características inerentes ao Cubismo:

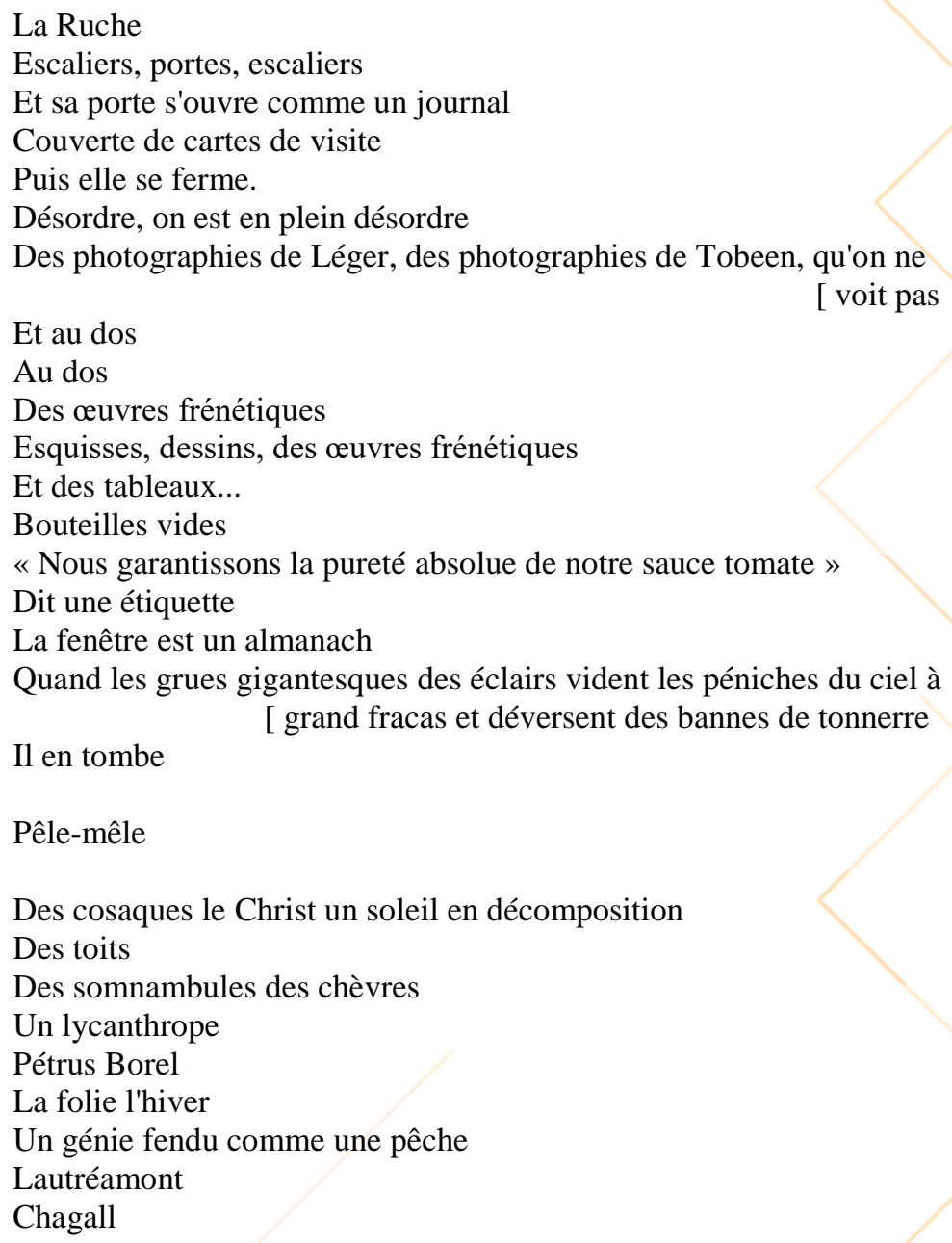


Pauvre gosse auprès de ma femme

Délectation morose

Les souliers sont éculés

Une vieille marmite pleine de chocolat

Une lampe qui se dédouble

Et mon ivresse quand je lui rends visite

Des bouteilles vides

Des bouteilles

Zina

(Nous avons beaucoup parlé d'elle)

Chagall

Chagall

Dans les échelles de la lumière ${ }^{16}$ (CENDRARS, 2006b, 97, 98).

La Ruche é a cité des artistes, imóvel que até os dias de hoje abriga os jovens talentos que anseiam instalar-se em Paris para desenvolver seus trabalhos. O local hospedou Léger, Chagall, Modigliani, Archipenko, Soutine, dentre outros artistas. No poema acima, Cendrars relata uma de suas visitas a esse lugar em que a arte, naquela época, era essencialmente vanguardista. Todos os ambientes de La Ruche refletiam o mesmo frenesi dos movimentos de vanguarda, sobretudo pela desordem, conturbação e desarmonia de tudo o que o poeta vê, de modo que a observação do local causa-lhe embriaguez - "[...] mon ivresse quand je lui rends visite" ${ }^{17}$. O êxtase de Cendrars faz com que ele descreva tudo o que se passa em sua visita em planos fragmentados, superpostos e simultâneos, aproximando-se da estética poética cubista. Nota-se o novo conceito de criação de imagens que, segundo Reverdy (1918, p. 3), une todos os pontos de vista captados pelo poeta. Portas, paredes, garrafas, rótulos, fotografias, obras frenéticas, sapatos, lâmpada, panela, janela, a presença de artistas e de assuntos discutidos compõem o relato desordenado de Cendrars e apresentam uma realidade desintegrada pela subjetividade do poeta.

\footnotetext{
${ }^{16}$ La Ruche/ Escadas, portas, escadas/ E sua porta abre-se como um jornal/ Coberta de cartões de visita/ Depois ela se fecha./ Desordem, estamos em plena desordem/ Fotografias de Léger, fotografias de Tobeen, que não se veem// E às costas/ Às costas/ Obras frenéticas/ Esboços, desenhos, obras frenéticas/ E quadros.../ Garrafas vazias/ 'Nós garantimos as pureza absoluta de nosso molho de tomate'/ Diz um rótulo/ A janela é um almanaque/ Quando as gruas gigantes dos relâmpagos esvaziam as barcaças do céu com intensos ruídos e derramam toldos de trovões/ Ele cai de lá// Desordem// Cossacos o Cristo um sol em decomposição/ Telhados/ Sonâmbulos cabras/ Um licantropo/ Pétrus Borel/ A loucura o inverno/ Um gênio partido como um pêssego/ Lautréamont/ Chagall/ Pobre criança perto de minha mulher/ Deleite lúgubre/ Os sapatos estão gastos/ Uma velha panela cheia de chocolate/ Uma lâmpada que se desdobra/ E minha embriaguez quando eu lhe faço visita/ Garrafas vazias/ Garrafas/ Zina/ (Nós falamos muito dela)/ Chagall/ Chagall/ Nas escalas de luz (tradução nossa).

17 “[...] minha embriaguez quando eu lhe faço visita" (tradução nossa).
} 
Em artigo para a Revista do Brasil, em 1924, Mário de Andrade identifica essas características da obra que envolvem subjetivação e fragmentação. O escritor denomina esses procedimentos de "lirismo subconsciente" ou "lirismo puro", que significava para o artista brasileiro um sistema lírico em que a ordem intelectual é substituída pela ordem subconsciente, de modo que o poeta se deixa levar pelo seu "eu profundo":

[...] Cendrars aproxima-se do lirismo puro mais do que nenhum outro poeta moderno. Nunca a subconsciência foi posta a nu com tanta exatidão e sinceridade como nos Dix-neuf Poèmes Élastiques (escritos em 1913 e 14). [...] nos Dix-neuf Poèmes Élastiques o lirismo subconsciente é expresso quase de modo integral. (ANDRADE, 1924 apud EULÁLIO, 2001, p. 387).

O lirismo puro ou subconsciente, do qual fala Mário de Andrade, já faz uma aparição no primeiro poema da obra, com nome muito sugestivo, "Journal "18. Adentrando profundamente em sua subjetividade, Cendrars se mostra em crise consigo mesmo e com seu métier de artista. Ele nos afirma: "J'ai même voulu devenir peintre"19 (CENDRARS, 2006b, p. 89). Essa afirmação nos remete às 28 pinturas feitas pelo poeta enquanto esteve hospitalizado, em 1913, para se recuperar de uma fratura na perna. Segundo Cendrars, esses quadros lhe abrem uma nova visão de si mesmo - "Ils m'ouvrent d'étranges vues sur moi-même [...]"20 (CENDRARS, 2006b, p. 89). Ao comparar-se com "um aeroplano em queda" 21 , o poeta afirma: "Je suis l'autre/ Trop sensible" ${ }^{22}$ (CENDRARS, 2006b, p. 90). Cendrars apropria-se da famosa sentença de Gérard de Nerval, “Je suis l'autre”, que exemplificava a vacilante identidade poética de Nerval. Do mesmo modo, Cendrars apresenta, nessa obra, a mesma instabilidade de seu gênio artístico.

\footnotetext{
18 "Diário" (tradução nossa).

19 "Eu até queria tornar-me pintor" (tradução nossa).

20 "Eles me abrem visões estranhas de mim mesmo [...]" (tradução nossa).

21 "On dirait un aéroplane qui tombe./ C'est moi"(CENDRARS, 2006b, p. 101). "Diríamos um aeroplano que cai./ Sou eu" (tradução nossa).

22 "Eu sou outro/ Muito sensível" (tradução nossa).
} 
Apropriando-se dos ideais da vanguarda expressionista, os "poemas elásticos" adentrarão os intensos impulsos da vida interior do poeta. Em vários versos, Cendrars demonstra uma sensação pungente - "Je suis inquiet" ${ }^{23}$ (CENDRARS, 2006b, p. 108); "Je suis toujours en fièvre"24 (CENDRARS, 2006b, p. 113); "Je suis mûr"25 (CENDRARS, 2006b, p. 115). Essa angústia está diretamente ligada ao seu alto nível de sensibilidade. Aumentada a audição, o poeta afirma ter "[...] de la musique sous les ongles" 26 (CENDRARS, 2006b, p. 111) e “[...] l'ouïe déchirée" 27 (CENDRARS, 2006b, p. 113). Extremamente sensível ao que vê, para Cendrars "Tout est couleur mouvement explosion lumière" ${ }^{28}$ (CENDRARS, 2006b, p. 115). Nada mais lhe é estático, tudo parece mover-se diante de seus olhos, por isso o poeta afirma: “Le paysage ne m'interésse plus/ Mais la danse du paysage/ La danse du paysage/ Danse-paysage"29 (CENDRARS, 2006b, p. 100). Todas essas sensações transformamse em sinestesia. O poeta ouve os gritos das cores que caem ${ }^{30}$, vê o acordeão do céu e vozes telescopadas ${ }^{31}$.

Essa conturbação espiritual revelada pelo poeta se refletirá diretamente em sua expressão e ordenará alguns dos princípios formais assumidos pela obra, aproximando-se novamente da estética expressionista. A confusão espiritual de Cendrars, em alguns momentos, extrapola as regras da língua francesa, causando rupturas sintáticas ou uma linguagem fragmentada, a aparição de neologismos, o uso das palavras em liberdade, e a intensa justaposição de imagens que obscurecem os sentidos dos versos. Desse modo, é possível compreender a característica "elástica” desta obra: conforme os versos de "Ma Danse", "Va-et-vient continuel/ Vagabondage spécial" 32 (CENDRARS, 2006b, p. 99), o "vai e vem" ou a "elasticidade linguística" dessa obra

\footnotetext{
23 "Eu estou inquieto" (tradução nossa).

24 "Eu estou sempre com febre" (tradução nossa).

25 "Estou bêbado" (tradução nossa).

26 “[...] música sob as unhas" (tradução nossa).

27 "[...] a audição atormentada" (tradução nossa).

28 "Tudo é cor movimento explosão luz" (tradução nossa).

29 “A paisagem não me interessa mais/ Mas a dança da paisagem/ A dança da paisagem/ Dança-paisagem” (tradução nossa).

30 "Les cris perpendiculaires des couleurs tombent sur les cuisses" (CENDRARS, 2006b, p. 101). "Os gritos perpendiculares das cores caem sobre as coxas" (tradução nossa).

31 "À travers l'accordéon du ciel et des voix télescopées" (CENDRARS, 2006b, p. 119). "Através do acordeão do céu e das vozes telescopadas" (tradução nossa).

32 "Vai e vem contínuo/ Vagabundagem especial" (tradução nossa).
} 
- ou seja, a fragmentação da linguagem, as rupturas sintáticas e os neologismos - são frutos da "elasticidade" ou distorção do próprio poeta, em seu caminho errante rumo ao encontro de sua identidade artística.

Além disso, o escritor de "poemas elásticos" cita em vários momentos um “dépouillement", ou seja, um despojamento que atinge desde a subjetividade do poeta até aos temas tratados pela poesia e também sua estética. Nesse sentido, a obra apresenta uma característica cara a todos os movimentos vanguardista: uma inclinação negativa que gerou ruptura e destruição de toda a tradição poética a fim de se construir uma arte absolutamente inovadora. Cendrars queria de fato "despir" a poesia das regras impostas pela tradição, como as normas para a elaboração de formas fixas ligadas ao verso, rimas, metro e ritmo, ou ainda as exigências para a elaboração de imagens. Por isso, Cendrars defende em seus "poemas elásticos" "Rimes et mesures dépourvues 33" (CENDRARS, 2006b, p. 120) e anuncia seu "Premier poème sans métaphores/ Sans images" ${ }^{34}$ (CENDRARS, 2006b, p. 119). Além de libertar a poesia das leis de versificação, o poeta almejava que sua obra pudesse simplesmente transmitir o mundo do qual faz parte e se desvencilhasse dos antigos temas caros à poesia, assim como também aspirava a Vanguarda. Por ter as "janelas abertas aos bulevares"35, a poesia de Cendrars recolhe da vida real elementos publicitários, como as diferentes tipografias, cores e ilustrações; cola textos de jornais; fala das viagens de trens e do cotidiano das grandes cidades. Para o poeta, "a poesia está na rua"36 (CENDRARS, 2006a, p. 42).

Em meio a essa preocupação com uma "poesia despojada", surge o anseio de se elaborar uma linguagem poética inovadora. É assim que também se manifesta a "elasticidade do poeta" nessa obra. Em entrevista radiofônica, Cendrars afirma: "A linguagem é uma coisa que me seduziu. A linguagem é uma coisa que me perverteu. A linguagem é uma coisa que me formou. A linguagem é uma coisa que me deformou.

\footnotetext{
33 "Rimas e medidas livres" (tradução nossa).

34 "Primeiro poema sem metáforas/ Sem imagens" (tradução nossa).

35 "Les fenêtres de ma poésie sont grand'ouvertes sur les boulevards et dans les vitrines" (CENDRARS, 2006b, p. 94). "As janelas da minha poesia estão bem abertas para os bulevares e para as vitrines" (tradução nossa).

36 Tradução nossa "La Poésie est dans la rue".
} 
É por isso que sou poeta, provavelmente é porque sou muito sensível à linguagem [... ${ }^{\prime 33}$ (CENDRARS, 2006a, p. 17).

Segundo o poeta, no excerto acima, os "poderes" da linguagem tanto o seduziram que inevitavelmente o aproximaram da poesia. Ao dizer que a linguagem foi para ele um instrumento de "perversão e deformação", Cendrars aproxima sua fala metaforicamente da "elasticidade" dos Dix-neuf poèmes élastiques, de modo que a alta sensibilidade do escritor à linguagem o teria "desfigurado", “distendido", tornando-o "elástico". Para superar esse elevado nível de percepção às "propriedades" das palavras e escrever, o poeta precisaria, assim, examinar-se minunciosamente e até mesmo dilacerar-se a fim de produzir sua arte - "L'homme qui se coupa lui-même la jambe réussissait dans le genre simple et gai" 38 (CENDRARS, 2006b, p. 120). Em resumo, pode-se dizer que a elasticidade dessa obra, assim, está também na intensa busca de Cendrars pela poesia dentro de si mesmo, de modo que precisaria distender-se e deformar-se a fim de conseguir exercer sua atividade artística.

Em toda a trajetória dos textos poéticos de Cendrars, muito antes de seu abandono do verso em 1924, o poeta ainda guardava consigo uma obra, que permaneceu inacabada. Em 1917, o escritor encerra em uma caixa os fragmentos dos manuscritos de $A$ u cœur du monde, obra que ficou esquecida durante 15 anos. Em entrevista radiofônica, Cendrars comenta o fato:

[...] em 1917 eu tinha acabado de escrever um poema [Au cœur $d u$ monde] que me surpreendeu por sua amplitude, por sua modernidade, por tudo o que eu inseri nele. A obra era completamente antipoética! Eu estava encantado com o resultado. E, nesse momento, eu decidi não publicá-la e deixar toda a poesia moderna se atrapalhar e se virar sem mim para ver o que aconteceria" (CENDRARS, 2006a, p. 18-19).

37 Tradução nossa. 'Le langage est une chose qui m'a séduit. Le langage est une chose qui m'a perverti. Le langage est une chose qui m'a formé. Le langage est une chose qui m’a déformé. Voilà pourquoi je suis poète, probablement parce que je suis très sensible au langage [...]”.

38 "O homem que cortou a própria perna era bem sucedido no gênero simples e alegre" (tradução nossa). 
É na antologia de poemas, referida acima, em que são inseridos os fragmentos de Au cœur du monde, que aparecem no final da obra, apesar de não terem sido cronologicamente o último trabalho do escritor. O poeta seduziu-se com a ideia de traçar o trajeto simbólico de sua obra, que partia dos textos de Du monde entier, primeira compilação dos poemas, que marcaram o nascimento de Cendrars como poeta moderno, e que culminava em $A u$ cour $d u$ monde, momento em que o escritor teria atingido o ápice de cosmopolitismo e de modernidade, conforme afirma o próprio poeta. Valendo-se dessa trajetória simbólica da obra de Cendrars, tal exemplar das poesias completas se chamará Du monde entier au cœur du monde.

Além disso, esse itinerário metafórico, que enlaça início e "fimm" da obra do poeta, estabelece um íntimo paralelo entre os primeiros poemas de viagem e as origens de seu gene familiar itinerante, e o último livro da antologia, Au cœur du monde, que marcaria o nascimento do poeta como homem moderno, situado na capital francesa, o “coração do mundo", já que Paris era o centro do cosmopolitismo e das inovações artísticas.

A obra é também marcada por uma grande crise existencial. O poeta que falava de sua família e de suas origens, como em Le Panama ou les aventures de mes sept oncles, agora afirma ser um homem sem passado e sem ascendência familiar: "Je suis l'homme qui n'a plus de passé [...]"39 (CENDRARS, 2006b, p. 304); "Je ne suis pas le fils de mon père [...] Je me suis fait un nom nouveau" ${ }^{40}$ (CENDRARS, 2006b, p. 305). O escritor afirma ter abandonado todos os laços familiares, inclusive seu nome e sobrenome: deixa de ser Fréderic-Louis Sauser para ser Blaise Cendrars - uma personalidade artística e, ao mesmo tempo, uma personagem ficcional. Além disso, o poeta deseja destruir completamente tudo o que restou de seu passado: “C'est pourquoi je ne regrette rien/ Et j'appelle les démolisseurs / Foutez mon enfance par terre/ $\mathrm{Ma}$ famille et mes habitudes"41 (CENDRARS, 2006b, p. 305).

Na obra, o poeta chega a indagar-se qual seria a sua nacionalidade, tamanho seu sentimento de cidadão universal: "Suis-je pélagien comme ma nounou égyptienne

\footnotetext{
52“Sou o homem que não mais tem passado" (tradução nossa).

40 "Não sou o filho de meu pai [...] Eu fiz para mim um nome novo" (tradução nossa).

41 "É por isso que eu não tenho arrependimentos/ E chamo os demolidores/ Jogue por terra minha infância/ Minha família e meus costumes" (tradução nossa).
} 
ou suisse comme mon père/ Ou italien, français, écossais, flamand comme mon grandpère ou je ne sais pas plus quel grand aïeul constructeur d'orgues en Rhénanie et en Bourgogne [...]"42 (CENDRARS, 2006b, p. 311). Por fim, o poeta afirma: "Pourtant je suis le premier de mon nom puisque c'est moi qui l'ai inventé de toutes pièces"43 (CENDRARS, 2006b, p. 311).

O escritor de nacionalidade dúbia, que criou uma identidade - artística e ficcional -, é assim o primeiro de sua nova linhagem, a genealogia do mundo moderno, a geração cosmopolita. Esse renascimento simbólico do escritor se manifesta em $A u$ cœur du monde por meio de duas metáforas: o ventre materno e a casa onde foi escrito o clássico Le Roman de la Rose.

Em sua caminhada noturna por Paris, o poeta afirma ter encontrado a casa onde nasceu: "Je sors dans la rue en courant. Me voici devant la maison/ [...] La maison où je suis né" ${ }^{44}$ (CENDRARS, 2006b, p. 307). Sabe-se que Cendrars não nasceu em Paris, mas em Chaux-de-Fonds na Suíça. O estranhamento aumenta quando o poeta afirma que no mesmo local onde ele teria vindo ao mundo é também onde Jehan de Meung havia escrito Le Roman de la Rose - "Je suis debout sur le trottoir d'en face et contemple longuement la maison/ C'est la maison où fut écrit Le Roman de la Rose"45 (CENDRARS, 2006b, p. 311). Fica evidente que Cendrars falava de um nascimento simbólico, que configura um novo dado biográfico para sua identidade ficcional. Paris, o "coração do mundo", centro do cosmopolitismo e das inovações artísticas da época, será também o local onde o poeta "renasceu" como artista moderno.

Le Roman de la Rose, grande clássico da literatura francesa, é um longo poema em versos octossílabos, escrito no século XIII. A obra é constituída em duas partes, que foram produzidas por dois escritores distintos. A primeira, composta por Guillaume de Lorris, retrata a história de um cortesão que busca conquistar sua amada, representada por uma rosa. O longo poema continuará a ser escrito, 40 anos depois,

\footnotetext{
42 "Sou pelágico como minha babá egípcia ou suíço como meu pai/ Ou italiano, francês, escocês, flamengo como meu avô ou sei lá qual antepassado construtor de órgãos em Renânia e em Borgonha [...]" (tradução nossa).

43 "No entanto eu sou o primeiro do meu sobrenome já que fui eu que o inventei do nada" (tradução nossa).

44 "Saio pela rua correndo. Eis que chego diante da casa./ [...] É a casa onde eu nasci" (tradução nossa).

45 "Estou parado na calçada defronte e contemplo demoradamente a casa/ É a casa onde foi escrito Le Roman de la Rose" (tradução nossa).
} 
por Jean de Meung. Esse novo fragmento é totalmente destoante do primeiro, de modo que o puro amor cortês de Lorris contrasta com a zombaria de Meung diante das relações conjugais ironizadas e seu discurso satírico contra as mulheres.

Renascer exatamente aonde a segunda parte do Roman de la Rose veio ao mundo faz de Cendrars um desdobramento da obra. Do mesmo modo que o poema medieval se renovava, pelas mãos de outro autor e com um prosseguimento completamente diferente do primeiro, o poeta de $A u$ cœur $d u$ monde também renascia: como homem cosmopolita, como artista moderno, com outro nome.

Além disso, diferente de suas origens que poderiam ser "demolidas", a antiga casa onde renascia Cendrars e o Roman de la Rose jamais seria destruída, nem mesmo por uma guerra: "Jamais une bombe allemande/ Ne te fera dégringoler/ Vieille maison de Paris/ Où fut écrit/ Le Roman de la Rose"46 (CENDRARS, 2006b, p. 308). Eis o modo como um homem comum, Frédéric-Louis Sauser, poderia perpetuar-se na história - assim como o clássico medieval francês de Lorris e Meung - sob o nome do artista Blaise Cendrars.

Juntamente com a casa da Rua Saint-Jacques, o poeta aponta outra morada simbólica de seu renascimento, o ventre materno: "Le ventre de ma mère /C'est mon premier domicilie" 47 (CENDRARS, 2006b, p. 309). O parto é descrito pelo poeta como um momento extremamente doloroso para ele, o que demonstra que esse renascimento não foi algo simples. Em diálogo com a mãe, o escritor relata o instante de sua "nova vinda ao mundo": "Mon crâne à ton orifice [...]/ Le grand muscle de ton vagin/Se resserrait alors durement/ Je me laissais douloureusement faire/[...] Si j'avais pu ouvrir la bouche/ Je t'aurais mordu/ Si j'avais pu déjà parler/ J'aurais dit:/ Merde, je ne veux pas vivre!"48 (CENDRARS, 2006b, p. 310).

$\mathrm{O}$ ventre materno e o momento do parto estão diretamente relacionados com a casa da rua Saint-Jacques. No final do mesmo poema, "Le ventre de ma mère", depois de descrever seu nascimento, o poeta acaba novamente diante do prédio onde

\footnotetext{
46 "Nunca uma bomba alemã/ te fará cair/ Velha casa de Paris/ Onde foi escrito/ Le Roman de la Rose" (tradução nossa).

47 "O ventre de minha mãe/ Foi meu primeiro domicílio" (tradução nossa).

48 "Meu crânio em seu orifício/ [...] O grande músculo de sua vagina/ Se apertava duramente/ Eu me deixava dolorosamente apertar/ [...] Se eu pudesse abrir a boca/ Eu teria te mordido/ Se eu já pudesse falar/ Eu teria dito:/ Droga, eu não quero viver!” (tradução nossa).
} 
foi escrito Le Roman de la Rose: “Je suis sur le trottoir d'en face et je regarde l'étroite et haute maison d'en face/ Qui se mire au fond de moi-même comme dans du sang"49 (CENDRARS, 2006b, p. 312). O sangue da mãe que o inundava, agora, está presente nessa "mirada" da casa, que vê a fundo o poeta. E o grito de terror ao nascer - "Merde, je ne veux pas vivre!" 50 - associa-se com a fachada da velha residência que também o aterroriza - “[...] cette maison m'épouvante [...]”" (CENDRARS, 2006b, p. 312). A ligação entre o parto e a casa passa a ser tão íntima que os arredores de Saint-Jacques são associados com a genitália feminina e sua profunda "fenda": "Ô rue Saint-Jacques! Vieille fente de ce Paris qui a la forme d'un vagin [...]/ Notre-Dame,/ Vieille fente en profondeur, long cheminement" 52 (CENDRARS, 2006b, p. 312; grifos nossos). Assim, é nessa "Paris em forma de vagina" ou "coração do mundo" que renasce o poeta, homem despregado de suas origens, poeta moderno e cosmopolita que tomou lugar de destaque nas movimentações vanguardistas.

"Do mundo inteiro ao coração do mundo": eis o percurso da obra de Blaise Cendras, que passou por vários países e expôs as grandes inovações vividas pela sociedade, a vanguarda e os movimentos artísticos modernos, sem deixar de retratar o poeta como a grande personagem, o centro de toda sua experiência moderna. Partindo da observação do mundo, Cendrars consegue atingir o mais profundo de si, o "coração" de sua existência.

\section{CONSIDERAÇÕES FINAIS}

É compreensível que Cendrars tenha abandonado a poesia, em 1924, para iniciar um novo percurso literário, na prosa. Como um escritor que gostava de lançar-se profundamente no seu trabalho de criação, o franco-suíço havia iniciado a atividade poética pela inspiração que recebeu de uma juventude aberta à descoberta do mundo e do novo

\footnotetext{
49 "Estou na calçada defronte e observo a estreita e alta casa da frente/ Que se reflete no fundo de mim mesmo como sangue" (tradução nossa).

50 "Droga, eu não quero viver!" (tradução nossa).

51 “[...] Essa casa me assusta [...]” (tradução nossa).

52 "Oh rua Saint-Jacques! Velha fenda dessa Paris que tem a forma de uma vagina [...]/ Notre-Dame,/ Velha fenda profunda, logo caminho" (tradução nossa).
} 
vivido pela sociedade, ao mesmo tempo que esgotou inúmeras possibilidades de experimentação do gênero que seu "eu-poeta" poderia ter criado; procurou tanto o novo, na poesia e no mundo, que acabou, ele mesmo, fragmentado pelo cosmopolitismo que atingiu. Sua poesia rumou à busca de si até que atingiu tanto a modernidade quanto um balanço de sua identidade, como o eternizado personagem Blaise Cendrars. Apesar de ainda ter projetos inacabados de obras poéticas, Cendrars pôde ter sentido a sensação de missão cumprida, de uma obra que era plural em experimentação no gênero, mas tão singular na temática: a busca de si, do mundo e da poesia.

Além disso, vale lembrar que no intuito de libertar o verso das convenções que lhe eram impostas, numa empreitada próxima à da vanguarda, Cendrars muitas vezes saltou as barreiras da poesia, como já dito, procurando inspiração em outras artes, como também chegou a um modelo de poesia prosaica, que recolhia os assuntos de seus versos nas coisas corriqueiras do mundo, como nas conversas e nos ambientes cotidianos. As últimas obras poéticas escritas, Documentaires e Feuilles de Route, de versos livres e brancos, extremamente descritivos e prosaicos abrem um caminho sem volta rumo à prosa. Falando sobre Feuilles de Route, Alexandre Eulalio comenta o trajeto da obra de Cendrars que culminou no abandono do verso. Segundo o crítico, o livro sobre a viagem para o Brasil

[...] opera uma transformação radical no verso cendrarsiano. [...] Ao buscar extrema simplicidade formal e linguística, Feuilles de Route despoja o discurso de todos os tratamentos experimentais até então praticados pelo seu autor. Desse ponto de vista, o Formose $e^{53}$ é o livro que conclui duplamente o ciclo iniciado com Les Pâques à New York, num período de absolutismo anafórico e imprecatório; assinala além do mais o abandono do verso como processo criador de Cendrars. (EULÁLIO, 2001, p. 31)

Esse despojamento do discurso poético que Cendrars foi progressivamente efetuando ao longo de sua obra coincidiu com o mise-en-scène de sua maior personagem de ficção: o escritor Cendrars, homem aventureiro e cosmopolita. O poeta vai estabelecendo, no decorrer de sua obra, a imagem de um homem que foi despojando

${ }^{53}$ Le Formose foi o primeiro livro de poemas que compôs o projeto da obra Feuilles de Route. 
sua identidade para tornar-se cidadão do mundo e escritor moderno. Pode-se dizer, assim, que o resultado de sua busca acaba na descoberta de um "eu" poético que leva em si a modernidade.

\section{REFERÊNCIAS BIBLIOGRÁFICAS}

ANDRADE, Mário. "Blaise Cendrars”. Revista do Brasil. São Paulo, março de 1924, pp. 214-213. In: EULÁLIO, Alexandre. A aventura brasileira de Blaise Cendrars: ensaio, cronologia, filme depoimentos, antologia, desenhos, conferências, correspondência, traduções. 2. Ed. Ver. E ampl./ por Carlos Augusto Calil. São Paulo: Edusp, 2001. p. 384- 394.

BÜRGER, Peter. Teoria da Vanguarda. Tradução de Ernesto Sampaio. Lisboa: Vega. 1993.

CENDRARS, Blaise. La Prose du Transsibérien et de la Petite Jehanne de France (artigo de Der Sturm). In: SIDOTI, Antoine. Genèse et dossier d'une polémique: La Prose du Transsibérien et de la Petite Jehane de France, Blaise Cendrars-Sonia Delaunay, novembre-décembre 1912-juin 1914. Paris: Lettres Modernes, 1987, p.99100.

Blaise Cendrars vous parle...: suivi de Qui êtes vous?, Le paysage dans l'oeuvre de Léger et de J'ai vu mourrir Fernand Léger. Org. Claude Leroy. Paris: Denöel. 2006a.

Du monde entier au cour du monde: Poésies complètes. Paris: Gallimard. $2006 b$.

. Páscoa em Nova-Yorque, Prosa do Transiberiano e outros poemas. Tradução de Sérgio Wax. Belém: Ed. Universitária UFPA. 1995. 
DEL PICCHIA, Menotti. "Blaise Cendrars. A Conferência de Amanhã" In: EULALIO, Alexandre. A aventura brasileira de Blaise Cendrars: ensaio, cronologia, filme depoimentos, antologia, desenhos, conferências, correspondência, traduções. 2. Ed. Ver. E ampl./ por Carlos Augusto Calil. São Paulo: edusp. 2001. p. 403, 404.

MILLIET, Sergio. “Cendrars: fantasia e realidade”. In: EULALIO, Alexandre. A aventura brasileira de Blaise Cendrars: ensaio, cronologia, filme depoimentos, antologia, desenhos, conferências, correspondência, traduções. 2. Ed. Ver. e ampl./ por Carlos Augusto Calil. São Paulo: Edusp. 2001. p.445-48.

REVERDY, Pierre. L'Image. Nord-Sud, Paris, v.2, n.13, p. 3-4, março de 1918.

WEISGERBER, Jean. (ed.) Les avant-gardes littéraires au XXe .siècle: Théorie; publié par le Centre d'Étude des Avant-gardes Littéraires de l'Université de Bruxelles. Budapeste: Akadémiai Kiadó. 1986. 2 v. 